\title{
The Impact of Feeding Factors on Holstein Dairy Farms Costs in Kosovo
}

\author{
Fatos Krasniqi $^{1,2}$, Muhamet Kamberi ${ }^{2 *}$, Enkelejda Emiri-Sallaku${ }^{1}$, Ragip Kastrati², \\ Myqerem Tafaj ${ }^{1}$
}

${ }^{1}$ Agricultural University of Tirana, 1000 Tirana, Albania

${ }^{2}$ University of Prishtina, Faculty of Agriculture and Veterinary, 10000 Prishtina, Republic of Kosovo

\begin{tabular}{l}
\hline A R T I C L E I N F O \\
Research Article \\
Received 23 April 2018 \\
Accepted 19 July 2018 \\
\hline
\end{tabular}

Keywords:

Holstein

Income

Cost

Feed

Milk

\begin{abstract}
A B S T R A C T
One-year investigation is carried out aimed at evaluating all incomes and costs with a specific focus on the impact of feeding factors in 12 Holstein dairy farms (in total 284 cows) in Kosovo. The cost of on-farm produced feeds; the price of purchased feeds and the price of milk were used for the analysis. All costs created during this period are duly registered and considered in the analysis. Economic analysis showed that prices of onfarm produced feed were much lower ( $30 € /$ ton for silages and for hay). Average daily feed cost was $2.33 € /$ cow/day, while milk income was only $4.9 € /$ d. Individual feed groups contributed to total milk cost as follows: silages with $0.04 € / \mathrm{kg}$, dry roughages with $0.02 € / \mathrm{kg}$, and concentrates with $0.10 € / \mathrm{kg}$, while all other factors taken $0.13 € / \mathrm{kg}$ of milk price. This study showed that feed was the largest farm expense making $68 \%$ of total farm costs.
\end{abstract}

\footnotetext{
$\frac{\text { *Corresponding Author: }}{\text { E-mail: muhamet.kamberi@uni-pr.edu }}$
}

DOI: https://doi.org/10.24925/turjaf.v6i9.1175-1183.1982

\section{Introduction}

Dairy cows make $55.6 \%$ of the cattle population, and though only $5.8 \%$ of the farms bred more than five cows, they are main milk suppliers for processing industry (Zeqiri et al., 2015). Local milk production covers about $84 \%$ of domestic consumption (MAFRD, 2015a). As estimated by the Ministry of Agriculture, Forestry and Rural Development (MAFRD, 2015a), average dairy farm size is between 1-5 heads, representing 94.2\% of all farms. According to Belegu et al. (2010), sustainable development of dairy sector requires not only an increased number of animals per farm or bigger farm size but also a better economic efficiency of dairy milk production. Although cow milk makes $97.8 \%$ of total milk production in the country, milk yield is still low and varies from 2.000 to $5.000 \mathrm{~kg}$ per cow and lactation (MAFRD, 2015a). As reported by Bytyqi et al. (2014), the average income from milk is $144.78 € / \mathrm{cow} / \mathrm{month}$. Same authors reported that income over feed takes 78.04 $€ /$ cow/month since average feed cost is 66.74 $€ /$ cow/month. After the inclusion of all other expenses, net income falls to $67.44 € / \mathrm{cow} /$ month per cow or 2.21 $€ /$ cow/day.

Holstein dairy cows are the main cattle population in Kosovo. However, the high genetic milk production potential of this breed is still used at the low extent, since many factors of influence in their performance are not properly respected. In this context, the feeding level and its quality is the main limiting factor.

The objective of this paper was, therefore, to carry out an economic assessment of the impact of feeding factors on Holstein dairy farm incomes and milk production costs.

\section{Material and methods}

Animals and Diets Data

The impact of feeding factors on milk production cost was investigated in a one-year study (from January 2015 to December 2015). The study was carried out in two regions (Dukagjini and Kosova Plain Regions) of Kosovo and included 12 Holstein dairy farms breeding 284 cows in total. Kosova Plain takes $57.6 \%$ of the total area of Kosovo while Dukagjini region is smaller with $36 \%$. In the Kosovo plain about 170-200 days/year are frost-free and the mean annual rainfall is about $650 \mathrm{~mm}$ with the average temperature being $10^{\circ} \mathrm{C}$ In the Dukagjini plain, the annual rainfall is slightly higher (about $780 \mathrm{~mm}$ ) and the frost-free period is slightly longer (up to 225 days), and the average temperature is $11^{\circ} \mathrm{C}$ indicating a pronounced Mediterranean climate influence in the 
western part of Kosovo (Kamberi, 2009; Bytyqi, 2015). There were two main criteria for including of dairy farms in this study: first, the farm size with more than 10 dairy cows per farm, and, second, dairy farms which have a contractual agreement with the national milk collection network. The size of the farms in terms of the number of animals and land owned or rented (ha) including Rent price $(€ /$ ha) is presented in Table 1 .
The diet composition and quality, daily average offered feed amount per cow and daily milk production per farm was measured. Six farms involved in this study applied separate feeding, while Total Mixed Ration (TMR) was applied to six other farms (Table 2). Daily average offered fed per cow was measured by weighing of daily feed amount offered to cows herd. Weighing of feed rests was not possible under usual farm conditions.

Table 1 The size of the farms and land area owned or rented (ha)

\begin{tabular}{|c|c|c|c|c|c|}
\hline & $\begin{array}{l}\text { No. of cows } \\
\text { /farm }\end{array}$ & $\begin{array}{c}\text { Total arable land area, } \\
\text { ha/farm }\end{array}$ & $\begin{array}{c}\text { Area owned, } \\
\text { ha/farm }\end{array}$ & $\begin{array}{c}\text { Area rented, } \\
\text { Ha/farm }\end{array}$ & $\begin{array}{l}\text { Rent price, } \\
€ / \text { ha }\end{array}$ \\
\hline \multicolumn{6}{|c|}{ Dukagjini Plain } \\
\hline$\overline{\mathrm{X}}$ & 25 & 14.6 & 3.6 & 11.0 & 412.5 \\
\hline Min & 12 & 8.3 & 2.5 & 5.0 & 325.0 \\
\hline Max & 47 & 30.5 & 5.0 & 27.0 & 500.0 \\
\hline \multicolumn{3}{|c|}{$\mathrm{N}=6$} & \multicolumn{2}{|c|}{ Kosova Plain } & \\
\hline$\overline{\mathrm{X}}$ & 22 & 8.83 & 3.33 & 5.50 & 225.0 \\
\hline Min & 11 & 6.5 & 2 & 4 & 200 \\
\hline Max & 36 & 12 & 6 & 8 & 250 \\
\hline
\end{tabular}

Table 2 Data on the types and the offered amount of feed used in dairy farms during study period

\begin{tabular}{|c|c|c|c|c|c|c|}
\hline & $\begin{array}{l}\text { Maize } \\
\text { silage }\end{array}$ & $\begin{array}{l}\text { Grass } \\
\text { silage }\end{array}$ & $\begin{array}{c}\text { Meadow } \\
\text { hay }\end{array}$ & $\begin{array}{c}\text { Alfalfa } \\
\text { Hay }\end{array}$ & $\begin{array}{l}\text { Wheat } \\
\text { straw }\end{array}$ & $\begin{array}{c}\text { Compound } \\
\text { concentrated feed } *\end{array}$ \\
\hline \multicolumn{7}{|c|}{ Farms used TMR ration $(n=6)$} \\
\hline Average & 8.0 & 1.3 & 1.2 & 0.9 & 1.1 & 4.8 \\
\hline$\%$ of ration $\mathrm{DM}$ & 46.24 & 7.51 & 6.94 & 5.20 & 6.36 & 27.75 \\
\hline Min & 6.9 & 0.0 & 0.0 & 0.0 & 0.0 & 4.5 \\
\hline Max & 9.7 & 2.6 & 2.6 & 3.0 & 1.7 & 5.4 \\
\hline SD & 1.2 & 1.1 & 1.1 & 1.5 & 0.8 & 0.3 \\
\hline \multicolumn{7}{|c|}{ Farms used Separate feeding $(n=6)$} \\
\hline Average & 9.2 & 0.0 & 1.4 & 2.8 & 0.0 & 4.3 \\
\hline$\%$ of ration $\mathrm{DM}$ & 51.98 & 0.00 & 7.91 & 15.82 & 0.0 & 24.29 \\
\hline Min & 7.7 & 0.0 & 0.0 & 0.0 & 0.0 & 4.0 \\
\hline Max & 11.0 & 0.0 & 4.4 & 4.7 & 0.0 & 4.7 \\
\hline SD & 1.2 & 0.0 & 2.1 & 2.2 & 0.0 & 0.3 \\
\hline
\end{tabular}

*The compound feed was composed of cereals (maize and wheat), wheat bran, soybean meal, sunflower meal, and mineral - vitamin premix for lactating dairy cows.

The ration composition was estimated by measurement of all ingredients used. Chemical analysis (Dry matter-DM, crude protein-CP, Acid Detergent FiberADF, Neutral Detergent Fiber-NDF), are performed by NIR Technique (using NIRS FOSS 6.500 apparatus and WinISI III software).

The Energy content of feed was calculated based on modified equations developed and revised by Adams (Ishler et al., 1996):

TDN, $\%=93.53-(1.03 \times \mathrm{ADF})$

$\mathrm{NEL}(\mathrm{Mcal} / \mathrm{lb})=[(\mathrm{TDN} \times 0.0245)-0.12] \times 0.454$

To convert Mcal/lb to $\mathrm{MJ} / \mathrm{kg} 9.2241$ factor was used. This factor is calculated from factors 4.184 (to convert Mcal to MJ) and 0.45359237 (to convert lb to $\mathrm{kg}$ ).

\section{Milk Production Data}

Milk production at farm level was measured by farmer on daily basis since all milk produced was delivered to milk collection network. The amount of produced milk was then converted to monthly and total production per cow. A 305-day milk production was calculated by division of the amount per year by the 1.1967 factor $(365 / 305)$.
Assessment of Dairy Farms Costs and Incomes

This study is based on data generated from the costs which made farms during production and all forms of incomes (exactly proven by milk collection network and the government direct payments or subsidies).

Because farmers were not properly keeping farm records (i.e. expenses, incomes, etc), for each farm in this study the following forms were designed:

- Farm infrastructure inventory (buildings + available mechanisation) to calculate the depreciation rate.

- Land inventory (owned or rented), to calculate the costs of land use and the area to be subsidised.

- Animals inventory to get the information for the number of cows, their physiological stage, as well as the amount of subsidy, get per head.

- On-farm feed production costs and expenses for purchase feed.

- The amount of feed offered to dairy cows.

- Production outputs of a dairy farm: i.e., milk, number of calves, the amount of manure.

- Other expenses made for labour, electricity, water, taxes, irrigation, sanitation, fuel.

- Veterinary health costs. 
From the beginning of the study, every cost and income happened on the farm was registered.

The cost of all feeds, either on-farm produced feeds or prices of feed ingredients purchased from the market, and the price of milk paid to farms was used for the calculations and economic assessment.

Average milk price paid to farms by milk collection network was calculated on monthly basis. Basically, the milk price was dependent on milk fat content (as a criterion of milk collection network), but farmers who managed to fit within requirements of MAFRD Administrative Instruction no. 02/2015 (MAFRD, 2015b), acquired an additional direct payment of 0.02 to $0.06 € / \mathrm{kg}$ milk delivered to milk collection network.

Based on the same regulation of the MAFRD, farmers were also subsidized based on the area they have cultivated with maize destined for feed and the number of dairy cows reared by the farm. The subsidy per head scheme (SPHS) and the subsidy per hectare of planted cereals (SHPC) represent the first direct support measures that were approved by MAFRD (Bajrami, 2016). All calves, heifers and cows removed from the farm and sold during the study period, as well as manure (used to fertilise own land or sold) were calculated and included in the farm income.

The yearly amount of manure produced was calculated following Nennich et al. (2003) and the income from manure was then calculated based on the price paid during the period of this study ( $2.5 € /$ ton manure).

Therefore, total farm income was the amount of income from milk, calves, and heifers, culled of cows, manure, plus subsidies.

Total dairy farm income $\left(\sum\right)=\mathrm{a}+\mathrm{b}+\mathrm{c}+\mathrm{d}+\mathrm{e}$

Where:

a: income from milk delivered to milk collection network;

b: income from calves and heifers sold;

c: income from culled of cows;

$\mathrm{d}$ : income from manure produced by the dairy farm;

e: total subsidies and direct payments by the government

\section{Total Subsidies Include}

- $\quad$ subsidy for milk delivered (0.02€-0.06€/kg milk),

- $\quad$ subsidy fora hectare of planted land $(150 € / \mathrm{Ha})$,

- $\quad$ subsidy per head (70€/cow),

Based on the results of costs and incomes, an assessment of the influence of feeding-related factors on cost and incomes of dairy farms were carried out according to Reisch and Zedies (1992) for two milk yield levels realized by studied farms, respectively 4000 $\mathrm{kg} / \mathrm{lactation}$ and $5000 \mathrm{~kg} / \mathrm{lactation}$.

Results of parameters of feeding cost and incomes of each farm included in this survey were statistically analysed using Analysis Tool pack of MS Office Excel 2007 (Descriptive statistics) and JMP statistical software (Inferential statistics). Analysis of Variance was used to test if there is any significant difference $(\alpha=0.05)$ and where differences existed, the Tukey test is used to evaluate the rate of difference.

\section{Results and Discussion}

Feed Production and Land Use

Feed is known to be a main determining factor of performance in livestock production and represents the main part of costs in milk production (Singh and Narang, 1993). The area of the arable land used for feed production, available mechanisation and farmer's knowledge about feed production, generally affects overall production costs. Providing adequate feeding to animals is crucial to maximizing production for dairy farms and utilisation of cow genetic potential.

Results on the structure of land (owned or rented) are presented in Table 1. As shown in this table farmers owned a very limited land area and therefore they were obligated to rent arable land. They pay a rent of 200 to $500 € /$ ha arable area for feed production.

The data on arable land available (owned and rented) show that studied dairy farms in average used 0.49 ha/cow for feed production, which can be considered as very limited in the context of a sufficient on-farm produced feeds. Moreover, $70.94 \%$ of the land available is rented which accounts about $111 € /$ cow.

Analysing factors affecting the technical efficiency of dairy farms in Kosovo, Bajrami et al. (2017) reported much higher land use (1.27 ha/cow) using interviewbased survey data from 243 dairy cow farms in Kosovo and also concluded that arable land use per cow has significant effect on milk productivity per cow.

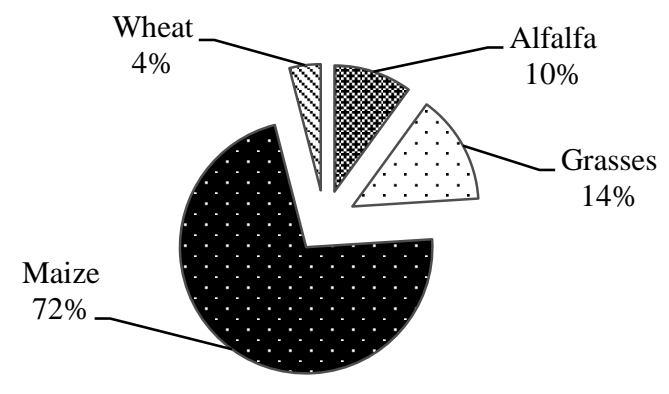

Figure 1 The structure of planted forages

From the analysis (Figure 1) of the arable land used for forage production, it may be seen that annual forages dominate perennials (76\% vs $24 \%$ ). The purpose of planted maize is exclusively for silage production and with $72 \%$ it dominated total land used by farms for feed production, while alfalfa (used as green feed and as hay), grasses from cultivated grassland and green wheat crops represented $10 \%, 14 \%$, and $4 \%$, respectively.

\section{Feed Costs}

The costs of feed and of Net Energy for Lactation (NEL), i.e. delivered energy for lactation by feeds, are analysed.

Table 3 summarizes the cost of on-farm produced feeds as well as prices of purchased feeds expressed in 
$€ / \mathrm{kg}$ (as fed basis), their energy content (MJ NEL/kg feed as fed basis), the cost of energy (€/MJ NEL), as well as the amount of feed offered to produce 4.000 or $5.000 \mathrm{~kg}$ milk.

According to Lima et al. (2015), prices of purchased feeds were variable and dependent on the production costs (Table 3), the yields, the prices of fertilizers, costs of machines hired for soil cultivation, prices of irrigation etc. The cost of on-farm produced feeds are calculated based on all expenses created during all stages of feed production on the farm, while for purchased feeds they are market prices paid by farmers during feed purchase.

On average $74 \%$ of the feeds used by studied dairy farms are on-farm produced feeds. All concentrated feeds (ingredients or compound feeds) were purchased. However, some farmers ground concentrate ingredients and mixed them to produce own dairy compound feeds. Production of on-farm dairy compound feed resulted in savings of about $30 € /$ ton of feed compared with purchased compound feed.

Maize silage which is generally considered as the main feed in extensive dairy feeding systems (Chase et al., 2009), took about $50 \%$ of the diet in our survey and it was produced by all studied dairy farms as main on-farm produced feed. Main components of dry forages were meadows hay followed by alfalfa hay. Chopped wheat straw was also used at TMR feeding, in order to fulfill requirement on effective fibre (crude fiber, NDF, $\mathrm{ADF}$ ).

Table 3 The costs and the share of on-farm produced feeds and purchased feeds in the ration of dairy cows at two moderate milk yield (4000 and $5000 \mathrm{~kg} / \mathrm{lactation} / \mathrm{cow})$.

\begin{tabular}{|c|c|c|c|c|c|c|c|}
\hline \multirow[t]{2}{*}{ Feeds } & \multirow{2}{*}{$\begin{array}{l}\mathrm{NEL} \mathrm{MJ} / \mathrm{kg} \\
\text { feed (as is) }\end{array}$} & \multicolumn{2}{|c|}{$€ / \mathrm{kg}$ feed, (as is) } & \multicolumn{2}{|c|}{$€ / M J ~ N E L$} & \multicolumn{2}{|c|}{$\begin{array}{c}\text { Share }(\%) \text { of ration at } \\
\text { different milk yield per cow }\end{array}$} \\
\hline & & On-farm & Purchased & On-farm & Purchased & $4.000 \mathrm{~kg}$ & $5.000 \mathrm{~kg}$ \\
\hline Maize silage & 2.4 & 0.03 & 0.05 & 0.0125 & 0.021 & 50.2 & 47.7 \\
\hline Grass silage & 2.0 & 0.05 & 0.07 & 0.025 & 0.035 & 2.1 & 6.0 \\
\hline Total fermented feeds & & & & 0.018 & 0.03 & 52.3 & 53.7 \\
\hline Meadows hay & 4.5 & 0.05 & 0.08 & 0.01 & 0.02 & 12.3 & 8.5 \\
\hline Alfalfa hay & 5.1 & 0.06 & 0.10 & 0.01 & 0.02 & 8.7 & 5.3 \\
\hline Wheat straw & 3.2 & 0.03 & 0.05 & 0.01 & 0.02 & 1.4 & 5.4 \\
\hline Total dry forages & & & & 0.01 & 0.02 & 22.4 & 18.9 \\
\hline Maize grain & 7.69 & 0.17 & 0.21 & 0.0221 & 0.027 & 11.0 & 12.0 \\
\hline Wheat & 7.21 & 0.16 & 0.20 & 0.0222 & 0.028 & 4.0 & 3.0 \\
\hline Wheat middling & 5.37 & 0.11 & 0.15 & 0.0205 & 0.028 & 3.0 & 3.9 \\
\hline Soybean meal & 7.51 & - & 0.43 & - & 0.057 & 5.0 & 6.0 \\
\hline Sunflower meal & 4.64 & - & 0.18 & - & 0.038 & 2.3 & 2.5 \\
\hline Premix & - & - & 0.95 & - & - & 0.03 & 0.03 \\
\hline Concentrate & & & & 0.04 & 0.045 & 25.3 & 27.4 \\
\hline
\end{tabular}

Table 4 The average contribution and the cost of energy for respective feed groups for two different yearly milk yield levels, $4.000 \mathrm{~kg} / \mathrm{cow}$ and $5.000 \mathrm{~kg} / \mathrm{cow}$.

\begin{tabular}{|c|c|c|}
\hline \multirow{2}{*}{ Parameters } & \multicolumn{2}{|c|}{ Milk yield per lactation, $\mathrm{kg} / \mathrm{cow}$} \\
\hline & 4.000 & 5.000 \\
\hline Milk production ${ }^{1}, \mathrm{~kg} / \mathrm{day}$ & 13.7 & 15.3 \\
\hline Offered $\mathrm{DM}^{2}, \mathrm{~kg} / \mathrm{day}$ & 17.47 & 17.5 \\
\hline Offered MJ NEL /day ${ }^{3}$ & 98.1 & 119.3 \\
\hline MJ NEL/ $\mathrm{kg}^{3}$ milk & 7.16 & 7.8 \\
\hline Crude protein, $\mathrm{g} / \mathrm{kg}$ milk & 107.1 & 119.7 \\
\hline Silages, $\%$ & 52.3 & 53.7 \\
\hline MJ NEL of silage/day & 51.3 & 64.1 \\
\hline Cost of silage energy, $€ / \mathrm{MJ} \mathrm{NEL}^{4}$ & 0.018 & 0.018 \\
\hline Daily cost of silage energy, $€ /$ day $^{5}$ & 0.9 & 1.1 \\
\hline Dry roughages, $\%$ & 22.4 & 19.0 \\
\hline MJ NEL of dry roughages/day & 22.0 & 22.7 \\
\hline Cost of roughage energy, $€ / \mathrm{MJ} N E L$ & 0.01 & 0.01 \\
\hline Daily cost of roughage energy, $€ /$ day $^{6}$ & 0.2 & 0.2 \\
\hline Concentrates, $\%$ & 25.3 & 27.3 \\
\hline MJ NEL of concentrates/ day & 24.8 & 32.6 \\
\hline Cost of concentrate energy, $€ / \mathrm{MJ}$ NEL & 0.04 & 0.04 \\
\hline Daily cost of concentrate energy, $€ /$ day $^{7}$ & 1 & 1.3 \\
\hline Total feed cost, $€ / \mathrm{kg} \mathrm{milk}^{8}$ & 0.15 & 0.17 \\
\hline
\end{tabular}


In general, on-farm produced feed resulted to be cheaper compared to the same feed purchased in the market. Economic analysis showed that prices of on-farm produced silages were $20 € /$ ton cheaper, while the difference in price of hays was $30 € /$ ton and $40 € /$ ton for meadow and alfalfa hay, respectively.

In order to better characterise the feeds and diets used, the cost of a unit of MJ NEL was analysed (Table 3). As seen from the Table 3, the cost of energy of purchased feeds is higher compared with on-farm produced feeds owing to their higher prices. The cost of energy unit (MJ NEL) of on-farm produced hays is about $50 \%$ lower than from purchased ones. The cost of energy unit (1 MJ NEL) from these feeds is however almost a half of the cost of concentrate. According to Reisch and Zeddies (1992), the cost of energy unit of roughages should be always lower than from the concentrates. A Higher cost of the energy unit of roughage feeds relativizes the changes in the diet composition, respectively the ratio of roughages to concentrate, as well as the effects that derive from them on feed costs. This high cost of roughages affected the average cost of the daily rations for both analysed yearly milk yield levels, i.e. $4.000 \mathrm{~kg}$ and $5.000 \mathrm{~kg}$ milk per cow. There is also high cost of energy unit (MJ NEL) of diet used for both milk production levels, which is probably related to the low yields of on-farm produced forages, high prices of fertilisers, mechanization, irrigation, land rent etc. A Higher cost of energy unit from silages compared with dry forages observed in this investigation is also related to the high price of the rent of land used for silage production. Hay is usually produced from the land owned by the farmer and because the hay is made from perennial plants, no ploughing, soil cultivation processes including seeding, is required each year which led to lower production costs of hay production, especially in comparison to grass silage.

\section{Feed and Nutrient Consumption for Milk Production}

An analysis of the structure of diet dry matter, the share of feed groups in relation to milk production at two milk production levels measured during this study, is presented in Table 5. It is observed that total offered DM for yield levels of $4.000 \mathrm{~kg}$ and $5.000 \mathrm{~kg}$ milk/cow was not different, but higher milk production was associated with higher energy and protein consumption, resulting in higher feed cost for milk production. Higher feed cost in second milk production level is a consequence of increased concentrate decreased dry roughage consumption of these cows. Emiri (1999) reported that protein consumption per unit of milk produced also reflects the level of fibres and indigestible proteins in the ration.

Analysis of offered DM, energy and protein for each milk unit produced (Table 4) at two milk yield levels achieved in the studied farms showed that, in general, consumption of these nutrients is considered to be high for both moderate levels of milk production (4.000 and $5.000 \mathrm{~kg}$ milk/lactation can be considered as moderate yield level compared to genetic potential of Holstein breed). This is eventually related to the calculations of feed consumption which are based on the offered feed without consideration of feed rests (hardly to be measured on usually farm conditions). According to Emiri (1999) feed rests can take $10-15 \%$ of offered feed.
Another interesting result is that the increase of milk yield is associated with consumption of less dry roughages and more concentrated feeds which are used to overcome nutrient deficiencies and lower availability of roughages. According to studies of Lang (1995), Tafaj (1996) and Steingass et al. (2002), Holstein dairy cows can produce up to $6.000 \mathrm{~kg}$ milk per lactation using very low concentrate level (less than $20 \%$ of diet DM), if highquality DM from silages and hays is offered supplemented with a minimal necessary concentrate amount.

\section{Analysis of Cost Structure}

Economic analysis of the contribution of the ration and the feed groups in milk price as well as milk net income is presented in Table 5.

The costs created were accordingly measured during the entire study and completed from the database recorded and maintained by the farm. The participation of the type of costs created during this investigation is presented in Figure 2. The main contributor of milk cost is definitely feed cost (from $51.7 \%$ to $65 \%$ of the milk cost). The highest share of the total feed cost is the cost of concentrate $(62.5 \%)$ feed followed by silages $(25 \%)$ and dry roughages $(12.5 \%)$.

The structure of costs

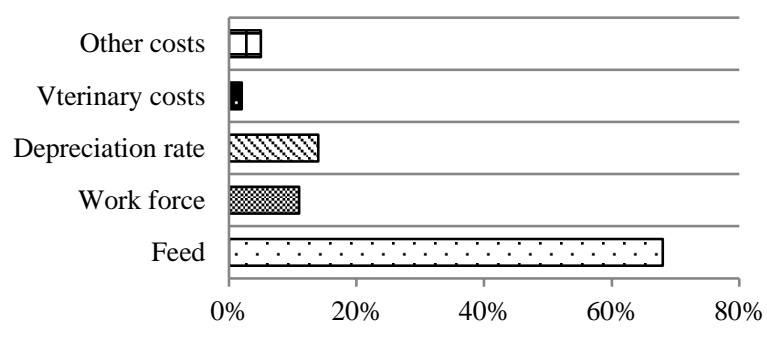

Figure 2 Share of different costs in the total farm costs

The average costs structure analysis of studied farms showed that feed costs took the main portion with $68 \%$ of all costs. It is important to underline that the feed use and feed cost are based on direct measurement in a significant number of middle- size and large-size dairy farms (12 farms with 284 cows, i.e. in average 24 cows/farm) and for a relatively long period of one year. This result is clearly higher than it from Bytyqi et al. (2014), who reported that feed made only $46.99 \%$ of all costs, though Martins et al. (2000) reports between $60-70 \%$ of feed contribution to all costs of closed (barn) breeding system of dairy cows. Findings of Zeqiri et al. (2016) that feed makes $69.2 \%$ of all variable costs ranging from 66.4 to 71.8 for farms breeding $1-10$ or $11-50$ cows respectively is also comparable with our findings. But all these surveys are based on interviews and not on the direct measurement on the farm. Depreciation rate, labour costs, veterinary expenses and other costs make $32 \%$ of total milk production costs. Under the definition of "other costs", expenses for fuel in feeding operations and manure removal within a farm, electricity, water, cleaning and sanitizing as well as maintenance costs for mechanization were included. 


\section{Production incomes, \%}

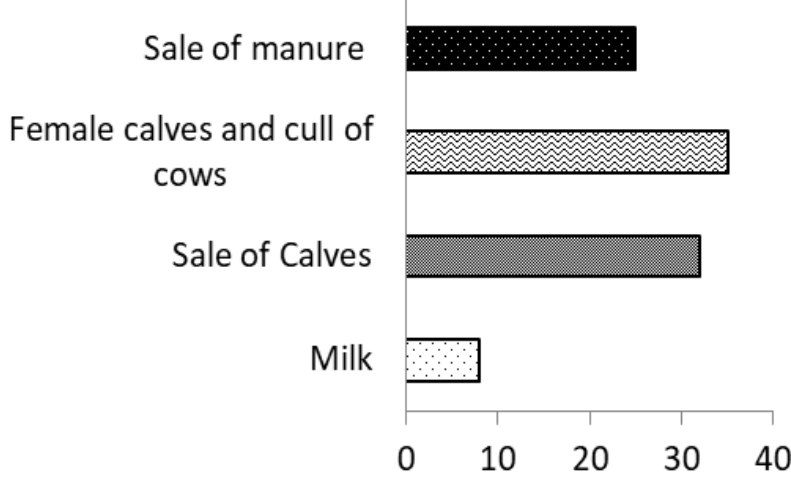

Figure 3The structure of production farm incomes (milk income without subsidies)

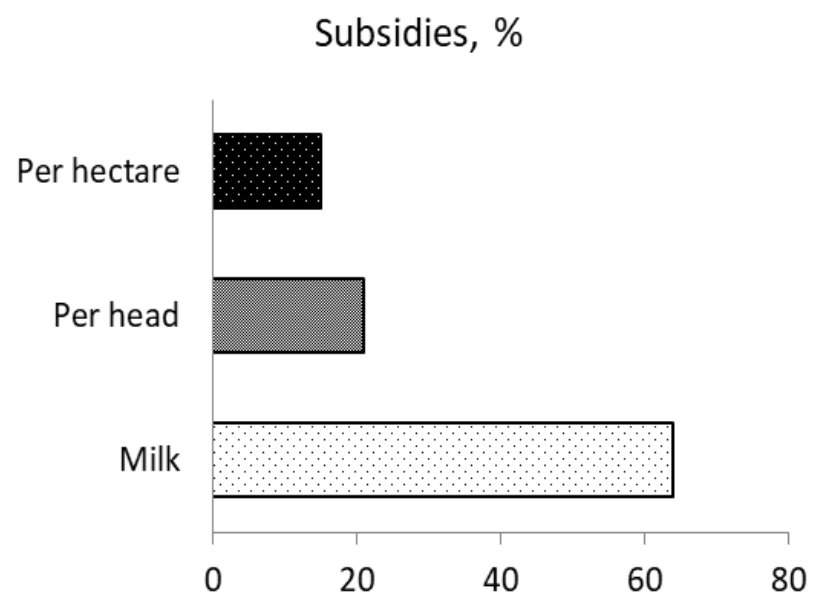

Figure 4 The structure of subsidies

\section{Total incomes, \%}

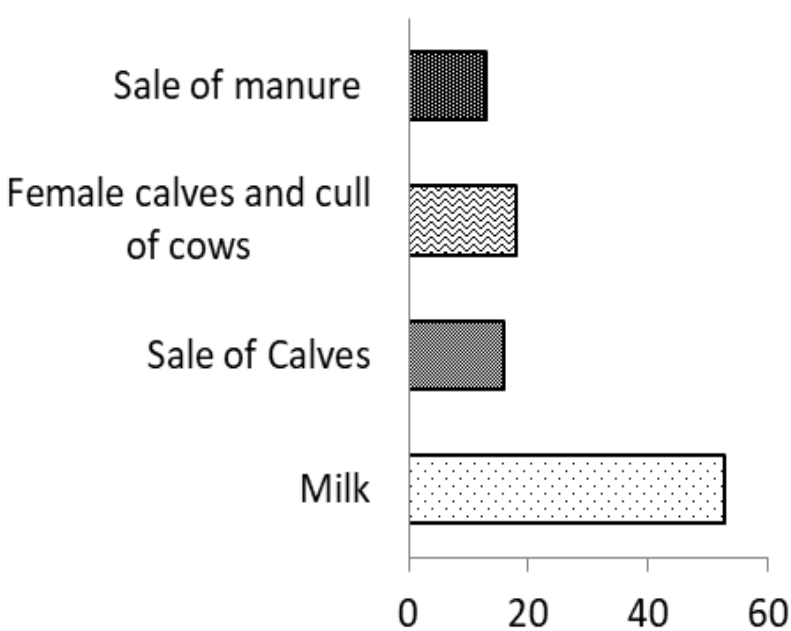

Figure 5 The structure of all incomes (milk with subsidies)

In general, the cost of milk production under usual conditions of Holstein dairy farms in Kosovo can be considered as high cost and milk as an expensive livestock product.

\section{Analysis of Dairy Farm Incomes}

Through Figures 3, 4 and 5, an analysis of the structure of incomes is given. Results show that an average sale price of milk to national milk collection network was $0.34 € / \mathrm{kg}$ milk, while production cost was $0.29 € / \mathrm{kg}$ milk. Analysis of the structure production incomes (Figure 3), unexpectedly, show that without subsidies, milk production makes the lowest farm income (only $8 \%$ ), even lower than manure. After subsidies are added (Figure 4 ) to the milk price the contribution of milk in total farm income increases to $53 \%$ (Figure 5).

With the average of $64 \%$, subsidies are the main farm income (Table 6), with some farms where subsidies are the sole income. As of the farm incomes, milk is the lowest farm income followed by sales of manure, calves, and heifers. There were very high variations of net milk income in studied farms. Results reviled that some farms hardly managed to maintain their profitability with cases of negative net milk income (minus $0.03 € / \mathrm{kg}$ milk) up to $0.04 € / \mathrm{kg}$ milk. This situation is observed in farms without subsidies because farms benefiting subsidies had net milk income of $0.05 € / \mathrm{kg}$ milk.

From 2009, there is an established subsidy direct payment programme in Kosovo based on the cultivated area of maize $(150 € / \mathrm{ha})$, on the number of cows ( $70 € /$ head). There is additional subsidy scheme in place from 2014 (MAFRD, 2015b) which offers farmers the benefit of $0.06,0.04$ and $0.02 € / \mathrm{kg}$ of milk if they succeed to meet certain milk quality/safety criteria and qualify for "Extra", "First" and "Second" class, respectively. Milk subsidies were the biggest part of direct payments for dairy farmers and took $64.1 \%$ of all subsidies. In this respect, the majority $(62.5 \%)$ of milk produced in farms involved in this study belonged in "Extra" Class, $7.69 \%$ in "First" and $29.8 \%$ in "Second" class. This type of income represented very important part of the milk income and averaged $0.05 € / \mathrm{kg}$ milk. These results do not fully agree with those reported by Zeqiri et al. (2016) who reported that the returns of the dairy farms originated only from the sale of milk and meat. Following these authors, the highest share of total returns for all categories of farms came from the sale of milk (93.7-95.5\%) and sale of calves (4.5-6.3\%).

Actually, no thoroughly evaluation the support scheme on the dairy sector in Kosovo is carried out, particularly on improving production, increasing land use, income and changing farm size (Bajrami, 2016). As reported by Pilvere et al. (2016) the only possible way farmers can do to increase profit is to maximize their production.

The cost reduction is another tool which farmers can use to increase profit and it is possible if low-cost available feed resources are more efficiently used. Further strategies are required in order to find more appropriate practices farmers can use to reduce the feed costs. Increasing on-farm produced roughage quality, feeding more on-farm produced of high quality roughage and reducing of concentrate feed (Lang, 1995; Tafaj, 1996; Steingass et al., 2002), are of course the relevant strategies also for dairy farms in Kosovo to increase milk production up to $6000 \mathrm{~kg} / \mathrm{cow}$ and to reduce the feed costs. This may contribute to increasing profitability but 
not all farmers are able to cope with all challenges and many of them quit their business.

However, subsidies have positively affected dairy farm business enabling them to either produce on-farm feed at a lower cost or to purchase required amounts of concentrates. This improved feeding level of animals and their production performance. Farms involved in this study bred between 11 and 47 dairy cows and used from 6.5 to 30.5 ha (Table 1). This difference resulted in different management practices and effectiveness of the use of resources. The largest farm (47 cows and 30.5 ha of land) produced more on-farm feed and more milk (16.54 kg/day/cow) at lower costs of milk $(0.27 € / \mathrm{kg}$ milk) as compared with smaller farms.

Table 5 Analysis of the effects of feed groups on milk production cost in dairy cow farms.

\begin{tabular}{|c|c|c|c|c|c|c|c|c|c|}
\hline \multirow[t]{2}{*}{$\mathrm{N}=12$} & \multirow[t]{2}{*}{ ADCD } & \multicolumn{3}{|c|}{$\begin{array}{l}\text { Portion of the feed group, } \\
€ / \mathrm{kg}\end{array}$} & \multicolumn{3}{|c|}{$\begin{array}{l}\text { The share of feed costs in the total milk cost, } \\
\qquad / \mathrm{kg}\end{array}$} & \multicolumn{2}{|c|}{$\begin{array}{c}\text { Net income, } € / \mathrm{kg} \\
\text { milk produced }\end{array}$} \\
\hline & & $S$ & DR & $\mathrm{C}$ & TMC & $\mathrm{FC}$ & $\mathrm{OC}$ & WHS & WS \\
\hline$\overline{\mathrm{X}}$ & 2.35 & 0.04 & 0.02 & 0.10 & 0.29 & 0.16 & 0.13 & 0.00 & 0.05 \\
\hline Min & 1.94 & 0.03 & 0.01 & 0.09 & 0.25 & 0.15 & 0.10 & 0.03 & 0.00 \\
\hline Max & 2.61 & 0.07 & 0.03 & 0.12 & 0.36 & 0.19 & 0.17 & 0.04 & 0.06 \\
\hline
\end{tabular}

ADCD: Average daily cost of diet, $€ /$ day, S: Silage, DR: Dry roughages, C: Concentrates, TMC: Total milk cost, FC: Feed cost, OC: Other costs, WHS: Without subsidies, WS: With subsidies

Table 6 Contribution of milk production and subsidies in dairy farm income, $(€$ or $\%)$

\begin{tabular}{l|cccc}
\hline Number of dairy farms & \multicolumn{2}{|c}{ Incomes $€$ /year } & \multicolumn{2}{c}{ Incomes, $\%$} \\
\hline \multicolumn{1}{c|}{$\mathrm{N}=12$} & Production & Subsidies & Production & Subsidies \\
\hline$\overline{\mathrm{X}}$ & 4.876 & 7.930 & 35.99 & 64.01 \\
MIN & 81.40 & 2.967 .24 & 0.77 & 49.31 \\
MAX & 17.867 .62 & 18.837 .12 & 50.69 & 99.23 \\
\hline
\end{tabular}

Table 7 Comparison of main parameters in Dukagjini and Kosova Plain

\begin{tabular}{|c|c|c|c|}
\hline Parameters & Dukagjini Plain & Kosova Plain & $\mathrm{P}$ value* \\
\hline On farm produced feed , \% & 74.72 & 72.58 & NS \\
\hline Purchased feed, $\%$ & 25.28 & 27.42 & NS \\
\hline Daily milk production, $\mathrm{Kg}$ & 12.24 & 11.74 & NS \\
\hline Silage, $\%$ & 53.97 & 51.80 & NS \\
\hline Dried forages, $\%$ & 18.30 & 23.66 & 0.0561 \\
\hline Concentrates, $\%$ & 27.73 & 24.54 & 0.0354 \\
\hline Total Ration, $€ /$ day/cow & 2.48 & 2.17 & 0.0052 \\
\hline Feed cost, $€ / \mathrm{kg}$ milk & 0.20 & 0.18 & 0.0095 \\
\hline $\mathrm{NEL}, \mathrm{MJ} / \mathrm{kg}$ milk & 9.99 & 9.77 & NS \\
\hline $\mathrm{CP} \mathrm{g} / \mathrm{kg}$ milk & 144.09 & 155.01 & 0.0286 \\
\hline
\end{tabular}

*Borderline of significance at $\mathrm{P} \leq 0.05$, NS: Non Significant $(\mathrm{P}>0.05)$

\section{The Effect of The Region}

In order to investigate the eventual influences of location/region, i.e., Dukagjini and Kosovo plain, on milk costs, the effect of factor "region" was tested using variance analysis.

All silage used in studied farms was produced on the farm, therefore no significant difference in its use was observed $(\mathrm{P}>0.05)$ though there are differences in its cost of production. All concentrates used in farms were purchased irrespective of the region. However, there is a significant difference in the use of concentrates between regions $(\mathrm{P}<0.05)$. Farms located in Dukagjini plain produced about $47.2 \%$ of the dried forages used, while Kosovo plain farms produced $54 \%$ of it. From the Table 7 , it may be seen that despite non-significant difference of the use of dried forages between farms of the two regions $(\mathrm{P}=0.0561)$, farms of the Kosova Plain used one kilogram per day more dried forages in their rations and about 0.5 $\mathrm{kg}$ concentrates less per day. This explains significantly cheaper daily ration cost and its influence on milk cost of Kosova Plain farms, due to cheaper on-farm produced dried forages and high prices of concentrates. However, it may be considered that observed differences between two locations/regions in this study are small and possibly more related to management practices than to the climate and geographic conditions because all studied dairy farms of both regions kept the cows in closed tie-up system.

\section{Conclusions}

Results of this study proved that feed and/or feedingrelated operations are the main expenses in all analysed farms contributing with $55 \%$ of the milk production cost in average or $68 \%$ of all farm costs. Concentrate feeds contribute with $34.48 \%$ followed by silages and dry roughages with $13.79 \%$ and $6.9 \%$ of milk costs, respectively. 
Results of the present study confirm that only onethird of farm incomes are generated from animal production (milk income, income from the sale of calves and heifers) with the lowest contribution of milk. Economic analysis of this study shows that subsidies are an important part of income and only $42 \%$ of farms managed to have a profitable business without subsides. This profit ranged from 0.01 to $0.04 € / \mathrm{kg}$ of milk per day. The other part, i.e. $58 \%$ of farms, were either at subsistent state (no profit- no losses) or the cost of milk produced was higher than the sale price for $0.03 € / \mathrm{kg}$ milk, which would generate losses and endanger the sustainability of dairy farm business. The reasons are different but mainly related to inappropriate feeding and management practice applied at dairy farms. In this context can be mentioned: low to moderate milk yield compared to genetic potential of Holstein breed, low quality of on-farm produced roughages, high costs of arable land rent, high costs of inputs necessary to feed production, using of relatively high level of expensive concentrate feed for low to moderate milk yield level, unbalanced feeding of cows during different lactation stages, etc. There are a lot of studies (Lang, 1995; Tafaj, 1996; Steingass et al., 2002) which proved that feeding strategies based on highquality on-farm roughages combined with very low level of concentrate, makes possible a milk yield of 5.000 and $6.000 \mathrm{~kg} / \mathrm{cow}$ at Holstein and other combined type cattle breed (Simental, Brown Suisse, etc.). This study also confirmed the significant low cost of on-farm produced feeds in comparison with purchased feeds. Therefore, such strategies can be applied also by dairy farms in Kosovo as the main way to increase milk production, to reduce milk costs and to increase the competitiveness of dairy farms. These strategies could be also considered by the scheme of subsidies for dairy farms, in order to increase milk production and quality, to reduce milk cost and to increase the profit and competitiveness of dairy farms in Kosovo.

\section{References}

Bajrami E, Wailes EJ, Dixon BL, Musliu A, Durand-Morat A. 2017. Factors affecting the technical efficiency of dairy farms in Kosovo. Journal of Central European Agriculture, 18(4): 823-840. DOI: 10.5513/JCEA01/18.4.1964. Available at https://www.researchgate.net/project/FactorsAffecting-the-Technical-Efficiency-of-Dairy-Farms-inKosovo.

Bajrami E. 2016. Evaluation of Agricultural Policy in the Dairy Sector in Kosovo and Efficiency Analysis at the Farm Level. Theses and Dissertations. 1720. http://scholarworks.uark .edu/etd/1720

Belegu M, Sallaku E, Rrapo P, Mustafaj S. 2010. The use of mathematical-economic modelling analysis of indicators by factors that influence productive and food in bovine milk farms. Journal of Institute Alb-Shkenca. ISSN 2073 www.alb-shkenca.org

Bytyqi H, Thaqi M, Hoxha F, Misini A, Haxhija B, Cabrera V. 2014. Economic Assessment of Dairy Farm Production in Kosovo. 11th European IFSA Symposium, Farming Systems Facing Global Challenges: Capacities and Strategies, Proceedings, Berlin, Germany, 1-4 April 20142014 pp.1486-1492 ref.9. http://ifsa.boku.ac.at/cms/fileadmin/ Proceeding2014/WS_2_7_Bytyqi.pdf
Bytyqi V. 2015. Natural resources and environmental problems in Kosovo Plain (In Albanian). PhD Thesis, University of Tirana Faculty of History and Philology, Department of Geography, Tirana Albania. http://www.doktoratura.unitir. edu.al/wp-content/uploads/ 2015/11/Doktoratura-ValbonBytyqi-Fakulteti-i-Historise-dhe-i-Filologjise-Departamentii-Gjeografise.pdf

Chase LE, Higgs RJ, Van Amburgh ME. 2009. Feeding lower crude protein rations to dairy cows-opportunities and challenges. Proc. Cornell. Nutr. Conf. Syracuse, NY. Pp: 235239. http://dairy.ifas.ufl.edu/rns/2012/3ChaseRNS2012.pdf

Emiri E. 1999. Evaluation of physiological effect of feeding in milk production and reproduction in black Holstein dairy cows (in Albanian). PhD thesis. Agricultural University of Tirana, Republic of Albania.

Ishler V, Heinrichs J, Varga G. 1996. From feed to milk: Understanding Rumen function. Extension circular 422, The Pennsylvania State University 1996. https://home.cc.umanitoba.ca/ plaizier/rumen.pdf (accessed 05/04/2018).

Kamberi AM. 2009. "Country Pasture/Forage Resource Profiles: Republic of Kosovo." Food and Agriculture Organization of the United Nations (FAO) (2009). http://catalog.ihsn.org/index.php/citations/25626

Lang G. 1995. For feed intake of dairy cows (In German). Dissertation. Universität Hohenheim, Lebendmasseentwicklung und Leistung bei Kühen der Rasse Deutsche Holsteins. 2. Mitteilung: Kühe mit mehreren Abkalbungen. Züchtungskunde, 74(3): 169-182.

Lima LP, Veloso CM, Silva FF, Pires AJV, Teixeira FA, Nascimento PVN. 2015. Milk production and economic assessment of cassava bagasse in the feed of dairy cows. Acta Sci. Anim. Sci. 37: 307-313. doi.org/10.4025/ actascianimsci. v37i3.26947. Available at: http://www. scielo.br/scielo.php?script=sci_arttext\&pid=S180786722015000300307

MAFRD. 2015a. Analysis of dairy market (in Albanian). Department of economic analysis and agricultural statistics. Ministry of Agriculture Forestry and Rural Development, Kosovo. http://www.mbpzhr-ks.net/repository/docs/ Tregu_i_qumeshtit_Final_15_10_2015.pdf

MAFRD. 2015b. Administrative Instruction No. 02/2015 for direct payments in Agriculture. Ministry of Agriculture Forestry and Rural Development, Kosovo. http://www.mbpzhr-ks.net/en/administrativeinstructions/?dy $=2015$

Martins AS, Zeoula LM, Prado IN, Martins EN. 2000. In situ ruminal degradability of dry matter and crude protein of maize and sorghum silages and some concentrated feed (In Portugese). Revista Brasileira de Zootecnia 28(5): 11091117. doi.org/10.1590/S1516-35981999000500029. Available at: http://www.scielo.br/scielo.php?script=sci_ arttext\&pid=S1516-35981999000500029

Nennich T, Harrison JH, Meyer D, Weiss WP, Heinrichs AJ, Kincaid RL, Powers WJ, Koelsch RK, Wright PE. 2003. Development of standard methods to estimate manure production and nutrient characteristics from dairy cattle. Conference Presentations and White Papers: Biological Systems Engineering. 1. http://digitalcommons.unl.edu/ biosysengpres/1

Pilvere I, Nipers A, Krievina A. 2016. Analysis of the factors affecting cost efficiency in the dairy industry in Latvia. Proceedings of the 2016 International Conference "Economic Science For Rural Development" No 41 Jelgava, LLU ESAF, 21-22 April 2016, pp. 252-259. Available at: http://llufb.llu.lv/conference/economic_science_rural/2016/ Latvia_ESRD_41_2016-251-258.pdf

Reisch E, Zeddies J. 1992. Introduction to agricultural management (In German). Eugen Ulmer GmbH Co, Stuttgart. 
Singh B, Narang MP. 1993. Indigestible cell wall fractions in relation to lignin content of various forages. Indian J. Anim. Sci., 63 (2): 196-200. Available at: https://www.feedipedia. org/node/14762.

Steingass H, Mack S, Lang GU, Tafaj M, Susenbeth A, Drochner W. 2002. Intensification of basic forage production and variation of concentrated feed supply: Factors of feed intake, biomass development and performance in cows of German Holstein breed. (In German). Züchtungskunde, 74 (3): 69-182.

Tafaj M. 1996. Studies on some feeding measures to improve the use of fiber-rich basic feed in ruminating animals (in German). Dissertation, University of Hohenheim, Germany.
Zeqiri M, Bytyqi H, Imami D, Biçoku Y. 2015. Dairy farmers awareness about food standards - the case of Kosovo. Agricultural University of Tirana. Albanian J. Agric. Sci.; 14 (2): 93-101. https://sites.google.com/a/ubt.edu.al/rssb/ revista_2_2015

Zeqiri M, Biçoku Y, Gjeçi G, Pire E. 2016. Dairy farms gross margin - case of Kosovo. Macedonian Journal of Animal Science, 6(2): 131-138. Available at: http://www.mjas. ukim.edu.mk/v6n2.htm 